\title{
RESEARCH INTO THE CAUSES OF INCREASED VIBRATION LEVELS ON THE DIESEL-ELECTRIC GENERATORS SET AT THE AIR TRAFFIC CONTROL- BELGRADE AIRPORT
}

\author{
Nikola P. Žegarac \\ Serbian Academy of inventors and scientists, Belgrade, Republic of Serbia \\ e-mail: zegaracnikola@vektor.net \\ ORCID iD: (iDhttp://orcid.org/0000-0002-1766-8184
}

DOI: 10.5937/vojtehg64-9455

FIELD: Machine Engineering, Electrical Engineerin ARTICLE TYPE: Original Scientific Paper ARTICLE LANGUAGE: English

\section{Summary:}

The paper presents the research into the causes of increased vibration levels on the diesel-electric generators at the Air Traffic Control-Belgrade Airport. The types of diesel generating sets are of the 175 KVA No-Break type (no interruption in electricity supply). Diesel generators serve as a backup power source (duplex system) in case of interruption in the regular electricity supply from the city grid for the systems and devices of the Air Traffic Control at Belgrade Airport. One diesel generator is in continuous operation, while the second diesel engine serves as a backup power system. The determined vibrodiagnostic methods for evaluating the technical functioning of diesel generators are an integral part of the documentation for the maintenance and overhaul of the No-Break diesel-generating set.

Key words: diesel-generator sets, measurement and analysis of vibrations, vibration levels, vibrodiagnostics, vibration parameters, technical functioning of diesel generators .

\section{Introduction}

During operation of the diesel generating set type No-Break power $175 \mathrm{KVA}$, the Air Traffic Control at Belgrade airport there was a problem of increased vibration levels at certain places aggregates. Diesel generators function as a reserve power source.

The working principle of No-Break diesel generators is such as to enable supply of all equipment and flight control systems without interruption in the power supply in case of disruption in the normal power supply from the city network. 
This means that all customers are still supplied with electricity from the generator diesel generating set, which is powered by an electric motor which is in the generating system drive. Devices and flight control systems must not remain any moment without power because in that case was marred by a system of air traffic control and air navigation safety.

In the event of an interruption in the power supply from the mains immediately starts using flywheel diesel generators, where there is electromagnetic coupling. This part of the system is always in constant rotation, along with an electric motor, an elastic tie rods and a generator generating set. Only a system is shown in Figure 1.

The applied methods are vibrodiagnostics reviews roadworthiness diesel generators set. Measurement and analysis of vibration on dieselelectric generators is administered with other users on all civilian and military airports in the territory of Serbia and Montenegro, and the diesel engines used in special-purpose facilities.

\section{Description of the plant and measuring point on diesel-electric generating sets type no-break, power $175 \mathrm{KVA}$}

In Figure 1, shows a schematic plant and measuring points on diesel generating sets type No-Break power 175 KVA (Žegarac, 1999), (Žegarac, 2000). Arrangements of electric generators: diesel motor, flywheel, electric motor and generator are mounted on a common frame (chassis) of aggregates, which is located below 12 pieces vibroizolators

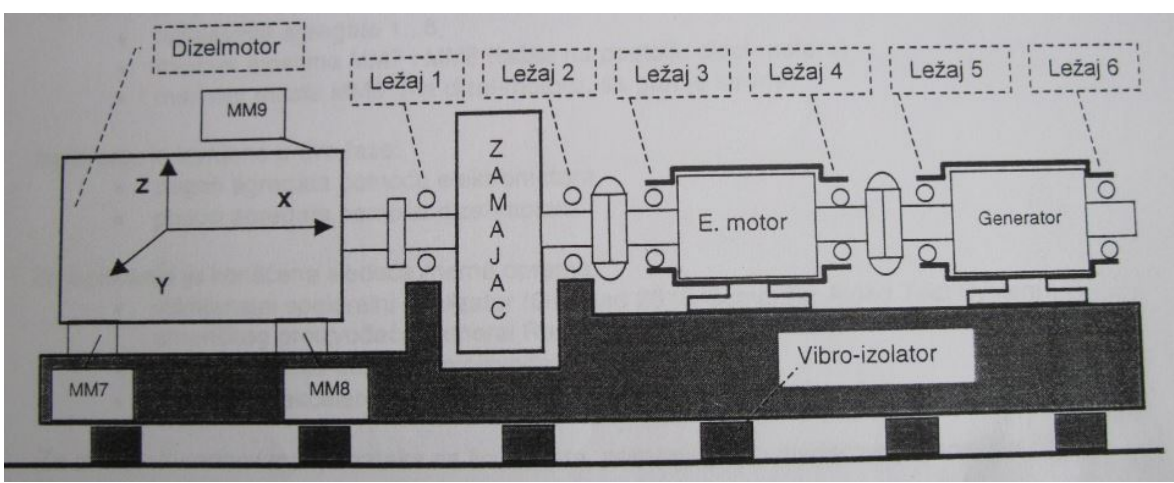

Figure 1 - Generating assembly scheme and the measuring points on the No-Break diesel-generating set

Puc. 1 - Схема электростанции и расположение вибродатчиков на дизельной электростанции типа No-Break, с мощностью 175 кBA

Slika 1 - Šema postrojenja i merna mesta na dizel-elektroagregatu tipa No-Break snage 175 KVA 
Basic information about the diesel engine:

- Manufacturer MAN Germany, Nürnberg, 6-cylinder in-line, watercooled engine,

- Type D2156 MTL

- Br. 501935 drive I / O

- Year in 1974.

- Engine power 204 PS

- RPM 1500 (o / min)

Basic data on electric motor:

- Manufacturer AEG Germany

- Type A5 315 S4

- Number of el. Engine 30 073.01-1

- Power $160 \mathrm{KW}$

- RPM 1500 (o / min),

Basic information about the generator:

- Manufacturer AEG Germany

- Type DKBH 284/04

- Number generator 73-464067

- excitation current $50 \mathrm{~V}, 2.8 \mathrm{~A}$

- Power 170 KVA,

- Nuber of revolutions $1500 / \mathrm{min}$

- Other features $3 \sim, \cos =0.8$, Y $400 \mathrm{~V}, 253 \mathrm{~A}$

Research methodology

The studies were conducted at 2 diesel-electric generators of the same type, the drive mode with electromotor- first case when there is a regular supply from the city network and the second case, dieselpowered engine when there is no regular supply of electricity from the city network. Measurement results and analysis are presented graphically and in tabular form. Applied Research Methodology is the same on both diesel generating set.The study was conducted based on the measurement of linear vibration: -bearings aggregates measuring point $1 \ldots \ldots .6$ - dimensional places MM 7 and 9 (points on the base of diesel generators), MM-dimensional areas 8 and 10 MM ( point on the upper side of the diesel engine). Research was conducted in three phases: aggregate by an electric actuator, measuring at working revs (1500 o / $\mathrm{min}$ ), actuator aggregates using diesel engines, measuring at working revs (1500 o / min) -monitoring behavior first generator in during his STARTING, to achieve a working speed in diesel engines. 
For testing we used the following measuring equipment: -multi channel analyzer-Gen Rad 2512 Computer Aided Test System, the American manufacturer General Dynamics Radio Spectrum, amplifierdimensional Danish manufacturer Brüel \& Kjær, -triaxial accelerometer (vibration sensor), Brüel \& Kjær, -optical speed sensors German manufacturer Hottinger Baldwin Messtechnick, -measuring amplifier for speed sensors, the manufacturer TRCpro - Novi Sad,

For the analysis and evaluation of data at the point of measurement, were used the following diagnostic methods: Analysis of RMS value (root mean square) speeds in all three coordinate directions, $x, y, z$ score sheet on the basis that according to the recommendations of Standard ISO 2372. Analysis of Crest -factor to assess the current state of the bearing unit. Spectrum analysis and harmonic analysis with the aim of diagnostics in low frequency domain. Analysis vibration rotor system in the unsteady state (empty promises or stopping), the generating I, (Ličen, 2003).

"Spin"- measurement of vibrations on the bearings was conducted in the frequency range from $0 \ldots 512 \mathrm{~Hz}$. Measurement of vibration during the start of the generating I, was carried out in the range of 0 $1000 \mathrm{~Hz}$.

\section{Measurement and analysis of vibrations to electricity generators and the electric drive mode}

The ways in which we can describe, and therefore vibrations and assess their impact on the mechanical construction:

- In the time domain,

- In the frequency domain, the frequency spectrum,

- Statistical indicators (scalar quantities).

Only vibration in the time domain may be from the standpoint of their, but other than that does not provide " impalpable" visualization, any other benefits. Therefore, the image vibration signal in the frequency domain, through various forms of frequency spectra much more comfortable.

RMS value is particularly interesting because it has a dimension of energy and talks about the energy content of the signal. Therefore, most of the standards that have allowed defined vibration levels linked to the RMS value as authoritative for the quantification of the vibration (Standard ISO 2370, Standard ISO 10816).

Recommendations for vibration in accordance with ISO 2372, ISO 10816, are given in Figure 2 and 3. 


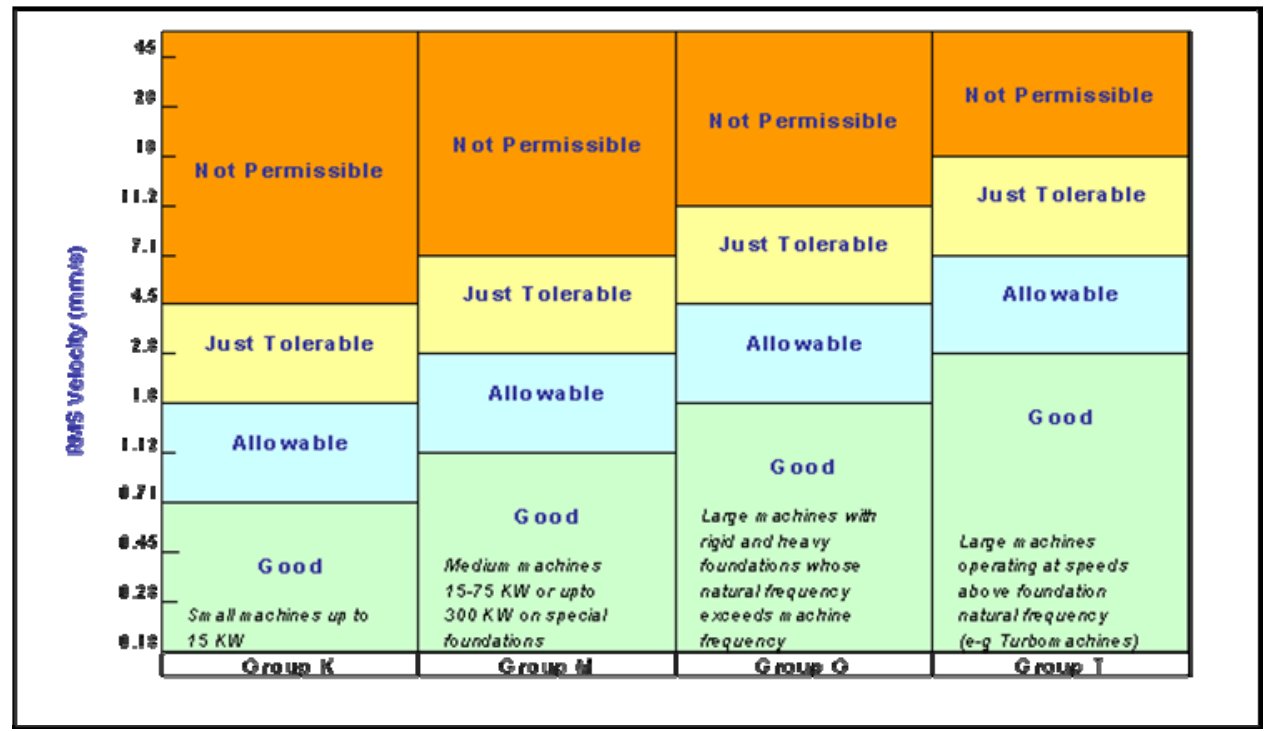

Figure 2 - ISO 2372 standard recommendations for vibrations

Puc. 2 - Рекомендуемые значения вибраций, согласно стандартам ISO 2372 Slika 2 - Preporuke za vibracije po standardu ISO 2372

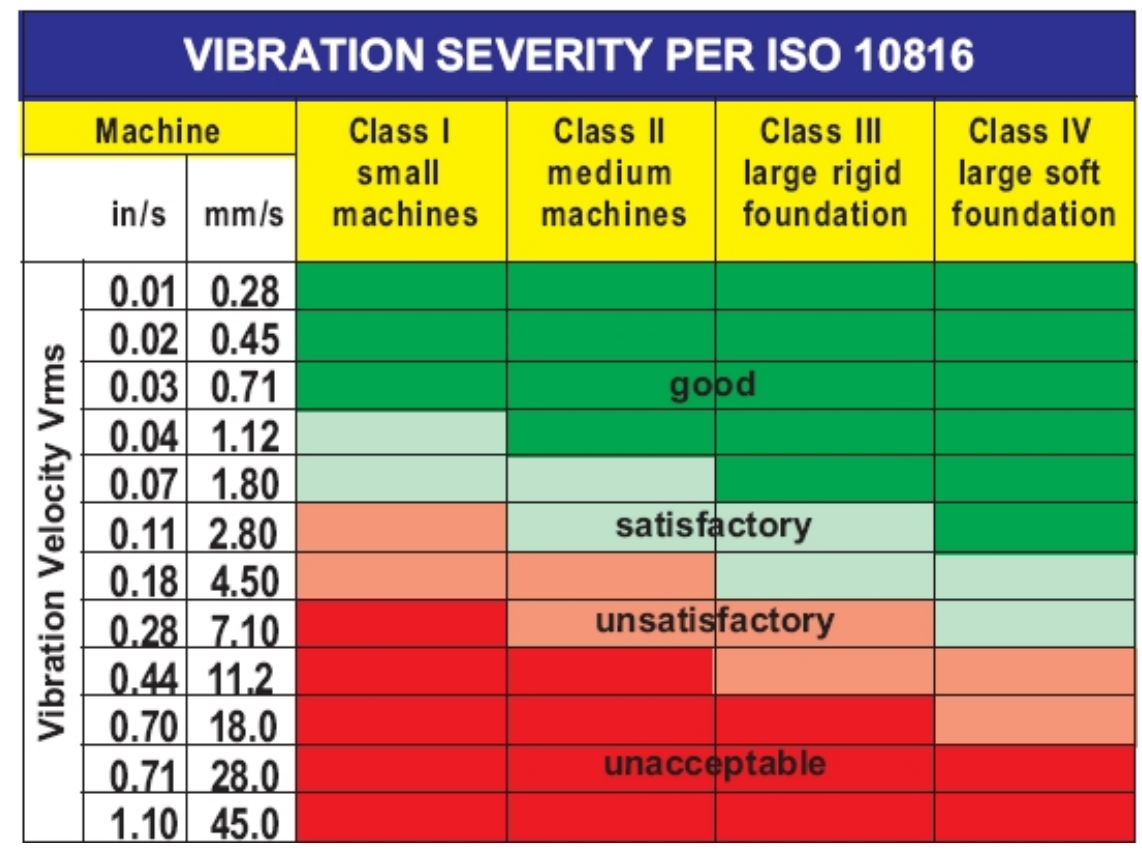

Figure 3 - ISO 10816 standard recommendations for vibrations

Puc. 3 - Рекомендуемые значения вибраций, согласно стандартам ISO 10816 Slika 3 - Preporuke za vibracije po standardu ISO 10816 
In the assessment of bearing condition, using a scalar indicator is used the most so. CREST factor in the limited time block, defined as the ratio of peak (Eng. Peak) value of the signal and its RMS value. The bed is usually not present only one type of failure, but a combination of several kinds of dismissal, as well as their number, the display is shown in Figure 4.

$$
\text { CREST factor }=\frac{\text { Peak }}{\text { RMS }}
$$

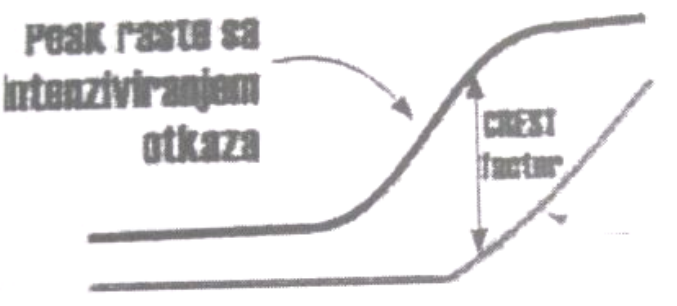

RMS masta sa intznziviraniem turais atkaza

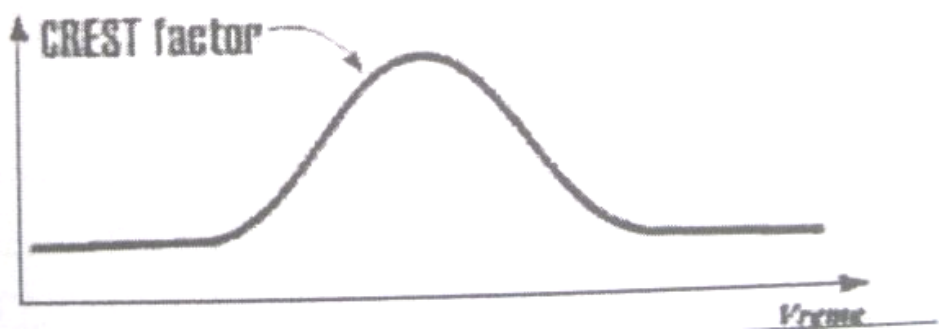

Figure 4 - Change of the CREST factor during the bearing life Puc. 4 - Изменения амплитудного фактора рабочего подшипника Slika 4 - Promena CREST faktora u toku radnog veka ležaja

The results of vibration measurements on electric generating set I, in an electric motor drive, are given in Table I, in a diesel engine facility in Table II. 
The first power unit: electromotor power

Table 1 - Measurement results for case 1: aggregate I, electromotor power Таблица 1 - Результаты измерения первого анализируемого случая: I электростанция с приводом от электродвигателя

Tabela 1 - Rezultati merenja za prvi analizirani slučaj: I agregat, pogon elektromotorom

\begin{tabular}{|c|c|c|c|c|c|c|c|c|c|c|}
\hline \multicolumn{8}{|c|}{ VIBRACIONO STANJE AGREGATA } & \multicolumn{3}{|c|}{ Tabela I } \\
\hline \multicolumn{3}{|c|}{$\begin{array}{l}\text { Datum ispitivanja: } \\
13.01 .1999 \text { god. }\end{array}$} & \multicolumn{6}{|c|}{$\begin{array}{c}\text { Postrojenje: } \\
\text { DIZELAGREGAT "SURČIN" }\end{array}$} & \multicolumn{2}{|c|}{$\begin{array}{l}\text { Pogon: } \\
\text { sa } \\
\text { elektromotorom } \\
\text { Br. obrtaja: } 1500 \\
\text { oimin }\end{array}$} \\
\hline \multirow{2}{*}{$\begin{array}{l}\text { LEZAJ } \\
\mathrm{Br} \text {. }\end{array}$} & \multirow{2}{*}{\multicolumn{2}{|c|}{$\begin{array}{c}\text { Ukupna RMS } \\
\text { vrednost } \\
\text { brzine[mm/s] }\end{array}$}} & \multirow{2}{*}{$\begin{array}{l}\text { CREST } \\
\text { faktor }\end{array}$} & \multicolumn{6}{|c|}{ HARMONICl [mm/s] } & \multirow{2}{*}{$\begin{array}{l}\text { STANJE } \\
\text { PO } \\
\text { ISO } 2372 \\
\end{array}$} \\
\hline & & & & 1 & II & III & IV & V & VI & \\
\hline \multirow{3}{*}{ L 1} & $\mathrm{X}$ & 0.867 & 2.77 & 0.668 & 0.199 & $=$ & $\cdot$ & $\cdot$ & - & \multirow{3}{*}{$\begin{array}{l}\text { DOZVO- } \\
\text { LJENO }\end{array}$} \\
\hline & $Y$ & 1.473 & 4.21 & 0.654 & 0.819 & + & + & - & $\cdot$ & \\
\hline & $z$ & 0.797 & 4.24 & 0.322 & 0.475 & $\cdot$ & $\cdot$ & - & $\cdot$ & \\
\hline \multirow{3}{*}{ L 2} & $x$ & 0.939 & 3.02 & 0.09 & 0.849 & $\cdot$ & $\cdot$ & $\cdot$ & $\cdot$ & \multirow{3}{*}{$\begin{array}{l}\text { DOZVO- } \\
\text { LJENO }\end{array}$} \\
\hline & $Y$ & 4.258 & 3.68 & 2.155 & 2.103 & $\cdot$ & 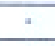 & $\cdot$ & - & \\
\hline & $\mathrm{Z}$ & 2.187 & 3.83 & 1.137 & 1.05 & $\cdot$ & $\cdot$ & $\cdot$ & $\cdot$ & \\
\hline \multirow{3}{*}{ L3 } & $X$ & 0.231 & 2.40 & 0.163 & 0.068 & - & $\cdot$ & $\cdot$ & $\cdot$ & \multirow{3}{*}{$\begin{array}{l}\text { DOZVO- } \\
\text { LJENO }\end{array}$} \\
\hline & $Y$ & 1.776 & 3.58 & 1.193 & 0.583 & $\cdot$ & " & $\cdot$ & $\cdot$ & \\
\hline & $z$ & 3.917 & 2.35 & 0.877 & 3.04 & $*$ & 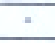 & $\cdot$ & - & \\
\hline \multirow{3}{*}{$\mathrm{L} 4$} & $x$ & 0.225 & 3.00 & 0.157 & 0.068 & 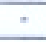 & - & - & - & \multirow{3}{*}{$\begin{array}{l}\text { DOZVO- } \\
\text { LJENO }\end{array}$} \\
\hline & $Y$ & 1.943 & 3.88 & 0.883 & 1.06 & $\cdot$ & $\cdot$ & $\cdot$ & $\cdot$ & \\
\hline & $\mathrm{Z}$ & 0.861 & 3.13 & 0.295 & 0.566 & $*$ & $\cdot$ & $\cdot$ & $\cdot$ & \\
\hline \multirow{3}{*}{ L 5} & $X$ & 0.447 & 4.38 & 0.07 & 0.377 & $\cdot$ & - & $\cdot$ & $=$ & \multirow{3}{*}{$\begin{array}{l}\text { DOZVO- } \\
\text { LJENO }\end{array}$} \\
\hline & $Y$ & 5.353 & 2.95 & 1.307 & 4,046 & - & - & 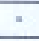 & - & \\
\hline & $z$ & 4.467 & 4.59 & 1.506 & 2.961 & - & 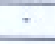 & $\cdot$ & - & \\
\hline \multirow{3}{*}{ L 6} & $x$ & 0.414 & 3.53 & 0.058 & 0.356 & - & $\cdot$ & $\cdot$ & - & \multirow{3}{*}{$\begin{array}{l}\text { DOZVO- } \\
\text { LJENO }\end{array}$} \\
\hline & $Y$ & 6.27 & 4.91 & 3.28 & 2.99 & - & $\pi$ & $\cdot$ & - & \\
\hline & $z$ & 3.089 & 4.31 & 2.306 & 0.783 & - & $\cdot$ & $\cdot$ & $\cdot$ & \\
\hline
\end{tabular}

RMS level of speed shows that the behavior of aggregate to ISO 2372 guidelines for all beds aggregates within acceptable limits. Also, it can be concluded on the basis of Crest factors, which lies in the range of $2 \ldots 4$, which is considered good for the behavior of the bearing Analysis Crest factors do not suggest that either of the beds significantly damaged.

Harmonics analysis can be concluded that the energy contained mainly in the first and the second harmonic (in the case of electric drives), which leads to imbalance.

Semi harmonics higher harmonics are not present a measurable, so that it can consider that the geometry (Alignment) system is relatively good. 


\section{Measurement and analysis of vibrations in the drive mode diesel-generating set I}

\section{The first unit: Drive diesel engine}

Table 2 - Measurement results for case 2: aggregate I, diesel engine power

Таблица 2 - Результаты измерения второго анализируемого случая:

І электростанция с приводом от дизельного двигателя

Tabela 2 - Rezultati merenja za drugi analizirani slučaj I agregat, pogon dizel motorom

\begin{tabular}{|c|c|c|c|c|c|c|c|c|c|c|}
\hline \multicolumn{8}{|c|}{ VIBRACIONO STANJE AGREGATA } & \multicolumn{3}{|c|}{ Tabela II } \\
\hline \multicolumn{3}{|c|}{$\begin{array}{l}\text { Datum ispitivanja: } \\
13.01 .1999 \text { god. }\end{array}$} & \multicolumn{6}{|c|}{$\begin{array}{c}\text { Postrojenje: } \\
\text { DIZELAGREGAT "SURĆIN" }\end{array}$} & \multicolumn{2}{|c|}{$\begin{array}{l}\text { Pogon: } \\
\text { sa dizel-motorom } \\
\text { Br. obrtaja: } 1500 \\
\text { ormin }\end{array}$} \\
\hline \multirow{2}{*}{$\begin{array}{l}\text { LEŻAJ } \\
B r .\end{array}$} & \multirow{2}{*}{\multicolumn{2}{|c|}{$\begin{array}{l}\text { Ukupna RMS } \\
\text { vrednost } \\
\text { brzine[mm/s] }\end{array}$}} & \multirow{2}{*}{$\begin{array}{l}\text { CREST } \\
\text { faktor }\end{array}$} & \multicolumn{6}{|c|}{ HARMONICl [mm/s] } & \multirow{2}{*}{$\begin{array}{l}\text { STANJE } \\
\text { pO } \\
\text { ISO } 2372 \\
\end{array}$} \\
\hline & & & & 1 & II & III & IV & V & VI & \\
\hline \multirow{3}{*}{ L 1} & $\mathrm{X}$ & 2.89 & 3.32 & 0.69 & 1.20 & 0.17 & 0.11 & 0.18 & 0.54 & \multirow{3}{*}{$\begin{array}{l}\text { DOZVO- } \\
\text { LJENO }\end{array}$} \\
\hline & $Y$ & 3.26 & 2.40 & 1.02 & 1.08 & 0.23 & 0.23 & 0.28 & 0.42 & \\
\hline & $z$ & 1.32 & 3.92 & 0.17 & 0.30 & 0.04 & 0.03 & 0.64 & 0.14 & \\
\hline \multirow{3}{*}{ L 2} & $x$ & 2.11 & 1.84 & 0.78 & 0.93 & 0.19 & 0.09 & 0.07 & 0.05 & \multirow{3}{*}{$\begin{array}{l}\text { DOZVO- } \\
\text { LJENO }\end{array}$} \\
\hline & $Y$ & 3.74 & 2.94 & 1.93 & 0.95 & 0.32 & 0.11 & 0.21 & 0.22 & \\
\hline & $z$ & 1.55 & 2.10 & 0.31 & 0.62 & 0.18 & 0.07 & 0.21 & 0.16 & \\
\hline \multirow{3}{*}{ L 3} & $x$ & 3.25 & 2.51 & 1.60 & 0.94 & 0.18 & 0,16 & 0.22 & 0.15 & \multirow{3}{*}{$\begin{array}{l}\text { DOZVO- } \\
\text { LJENO }\end{array}$} \\
\hline & $Y$ & 3.56 & 3.45 & 0.39 & 0.85 & 0.32 & 0.78 & 0.34 & 0.88 & \\
\hline & $z$ & 3.11 & 3.49 & 0.76 & 1.85 & 0.14 & 0.07 & 0.15 & 0.14 & \\
\hline \multirow{3}{*}{ L 4} & $x$ & 3.12 & 2.35 & 1.60 & 0.85 & 0.17 & 0.17 & 0.21 & 0.12 & \multirow{3}{*}{$\begin{array}{l}\text { DOZVO- } \\
\text { LJENO }\end{array}$} \\
\hline & $Y$ & 4.21 & 3.50 & 0.12 & 0.35 & 1.14 & 1.84 & 0.17 & 0.59 & \\
\hline & $z$ & 2.71 & 2.09 & 0.87 & 0.60 & 0.58 & 0.39 & 0.17 & 0.10 & \\
\hline \multirow{3}{*}{ L 5} & $x$ & 4.81 & 1.95 & 1.62 & 2.24 & 0.25 & 0.06 & 0.37 & 0.27 & \multirow{3}{*}{$\begin{array}{l}\text { DOZVO- } \\
\text { LJENO }\end{array}$} \\
\hline & $Y$ & 5.66 & 2.53 & 1.00 & 0.62 & 1.46 & 1.46 & 0.43 & 0.69 & \\
\hline & $z$ & 4.41 & 3.25 & 1.07 & 1.70 & 0.53 & 0.65 & 0.33 & 0.13 & \\
\hline \multirow{3}{*}{ L 6} & $x$ & 4.82 & 2.13 & 1.80 & 1.97 & 0.20 & 0.13 & 0.47 & 0.25 & \multirow{3}{*}{$\begin{array}{l}\text { DOZVO- } \\
\text { LJENO }\end{array}$} \\
\hline & $Y$ & 3.71 & 4.14 & 0.61 & 0.71 & 0.50 & 1.23 & 0.28 & 0.38 & \\
\hline & $z$ & 4.44 & 2.64 & 2.10 & 1.04 & 0.11 & 0.57 & 0.19 & 0.43 & \\
\hline \multirow{3}{*}{ MM7 } & $x$ & $\cdot$ & - & 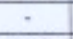 & - & - & - & - & - & \\
\hline & $Y$ & 5.56 & 3.35 & 1.13 & 0.73 & 2.84 & 0.21 & 0.28 & 0.37 & \\
\hline & $z$ &. & $\cdot$ & 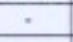 & $\cdot$ & 1.90 & $\cdot$ & - & - & \\
\hline \multirow{3}{*}{ MM8 } & $x$ & - & $\cdot$ & $\cdot$ & $\cdot$ & $\cdot$ & 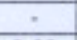 & $\cdot$ & & \\
\hline & $Y$ & 9.06 & 4.26 & 0.72 & 1.96 & 1.97 & 0.60 & 0.63 & 3.18 & \\
\hline & $z$ & $\cdot$ & - & - &. & $\cdot$ & $\cdot$ & $\cdot$ & $\cdot$ & \\
\hline \multirow{3}{*}{ MM9 } & $x$ & $\cdot$ & $\cdot$ & - & - & - &. & - &. & \multirow{3}{*}{. } \\
\hline & $Y$ & - & - & - &. & 9.26 & - & - & 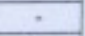 & \\
\hline & $z$ & - & - & - & 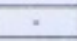 & 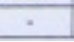 & - & 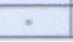 & - & \\
\hline
\end{tabular}

In the drive with a diesel engine, there is a strong increase in even harmonics (II, IV, VI), which is associated with the excitation of the ignition stroke at 6-cylinder, four-stroke engine. Nevertheless vibration levels lie relatively low, but some service or replacement parts on aggregate at this stage is not necessary. 
It is obvious that when operating the generating set is in standby drive with a diesel engine, vibratory situation differently, and that the initiative even harmonics causes slightly increased vibration.

The analysis of radial deformation in the $Y-Z$ level in all aggregate bearings $\mathrm{L} 1$.......L6.

Due to the volume of research in this paper it is shown only for bed L1 and L2, a general assessment of the technical condition of the entire generating set and displayed through the final note.

Condition on the bearing L1: Energy radial movement of the first bearing is the most concentrated within the first harmonic. The which phase shift between the signals is close to the corner of 90 indicates the combination of a mild imbalance and other disorders of the first order. There is an element that was because of its location close to the fourth harmonic, and as such is likely induced by diesel engines. The first two harmonics of vibration in the $Y$ direction are significantly higher than the corresponding ones of the Z-direction, which is logical in view to the elasticity of the system is higher in the $\mathrm{Y}$ direction, which enables a large amplitude of vibration, the display on Figure 5.

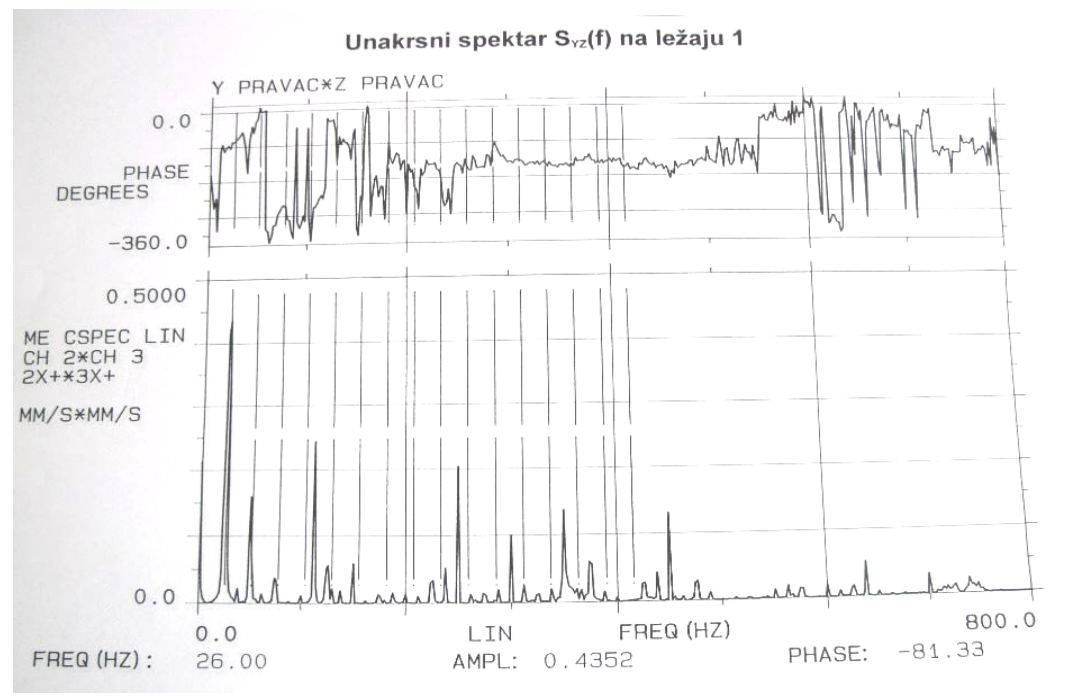

Figure 5 - Syz(f) Cross spectrum on bearing $L 1$

Puc. 5 - Взаимный спектр Syz(f) на подшипнике L1

Slika 5 - Unakrsni spektar Syz(f) na ležaju L1

Condition on the bearing L2: In the cross spectrum Syz, bearing L2 fall "in" eyes, frequency components around zero frequency (i.e DC component). DC component is significantly more pronounced in the $Y$ direction than in the $Z$ direction which indicates its origin: vibroizolators are much "softer" in the $Y$ direction than in the $Z$ direction which creates a slow pace so move. Swimming-rolling (rolling) system along the $X$-direction. This 
shift can be significant in relation to the vibration of the bed, but do not affect its status (high DC component does not damage the bearing).

Other frequency components by an amount similar to the amplitude condition as the previous bearing, the phase shift is slightly different, the first radial harmonic vibrations in $Y$ and $Z$ direction are very close to the stage, is associated with the excitation of the diesel engine, see Figure 6

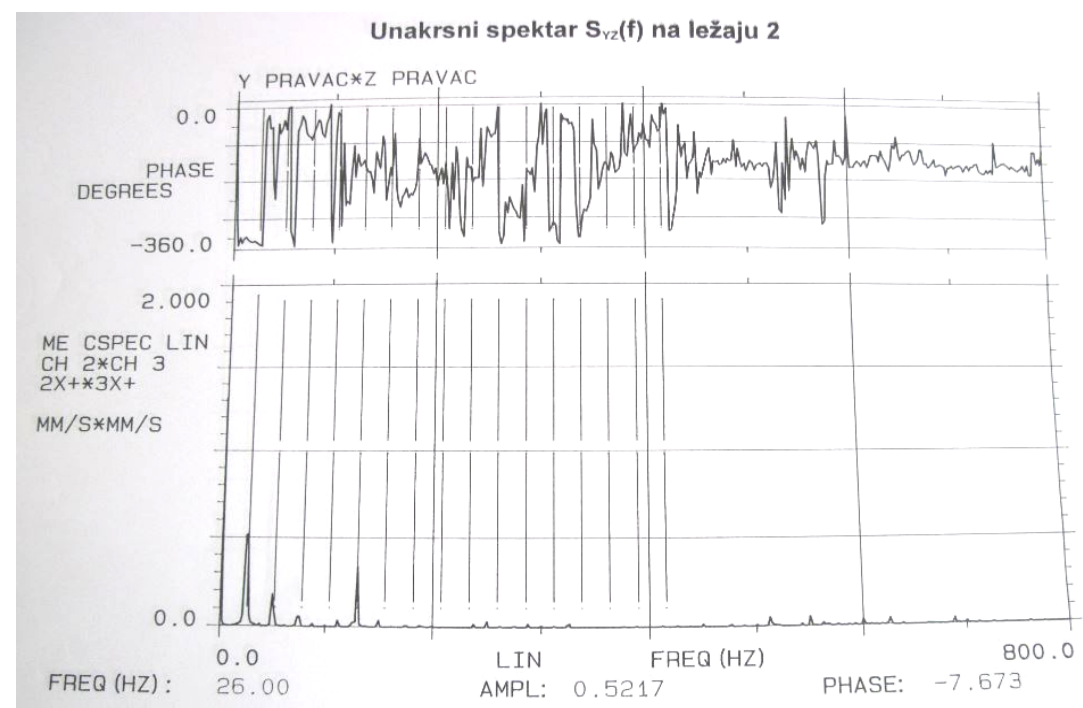

Figure 6 - Syz(f) Cross spectrum on bearing $\mathrm{L} 2$

Puc. 6 - Взаимный спектр Syz(f) на подшипнике L2 Slika 6 - Unakrsni spektar Syz(f) na ležaju L2

\section{Measurement and analysis of vibration during start-up and operation of a diesel engine}

In plants from the standpoint of the vibrating "passport" order to obtain sheet were measured at the aggregate of vibrations in the STARTINGpowered diesel engine. The measurement was carried out by the analyzer GenRad 2515 and SPIN software package. The method consists in the fact that continually during STARTING (or stopping) measures the vibrations to defend bearings, while the number of revolutions.

In addition, the program for a given speed change (for example, $20 \mathrm{r}$ I min), shall record the vibrations of the same frequency spectra account. , so-called "look up".

These spectra are shown in three-dimensional form (spectral maps) or in the form of Campbell's diagram. These presentations provide insight into the forced frequency (rows) and their own interest-frequency system, as well as the resonance phenomenon, or critical speeds, from "order 
tracking "In addition, it is possible to follow the lines where it is possible to identify the resonances that are excited harmonics.

The measurement was carried out on a bed $L 2$ ( $Z$ and $Y$ direction), as well as on the bearing $L 5$ (Y-direction). Only spectral maps, auto spectrum for bed L2, LAS is given in Figure 7, but for bed L5, SYY in Figure 8 and Campbell's diagram of the FFT, SYY, for bearings L2, in Figure 9.

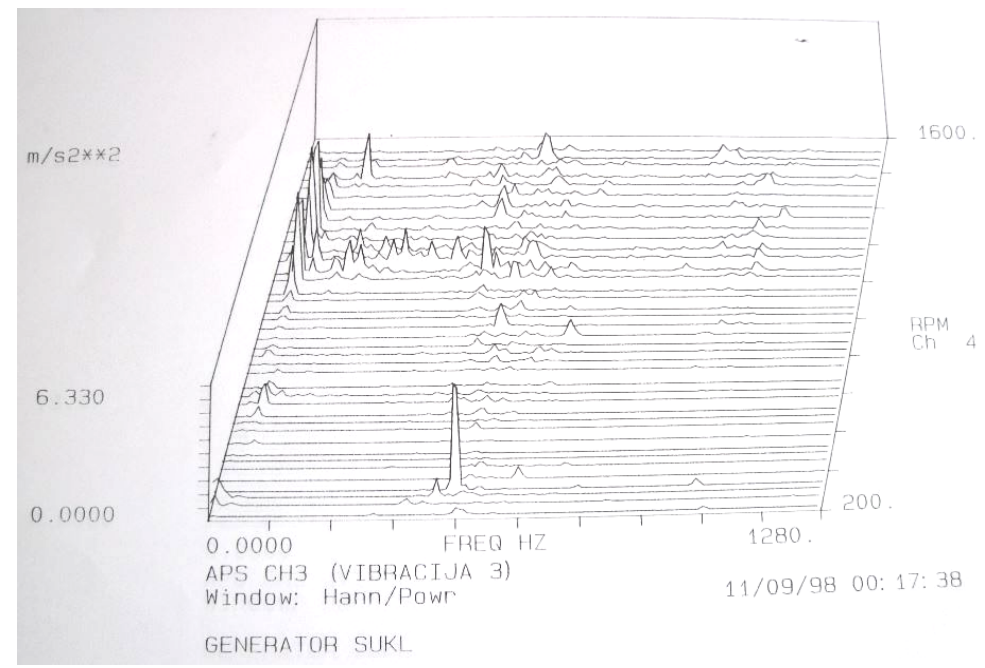

Figure 7 - Spectral map, Szz autospectrum, bearing L2

Рис. 7 - Спектральная карта, Szz авто-спектр, подшипник L2

Slika 7 - Spektralna mapa, autospektar Szz, ležaj L2

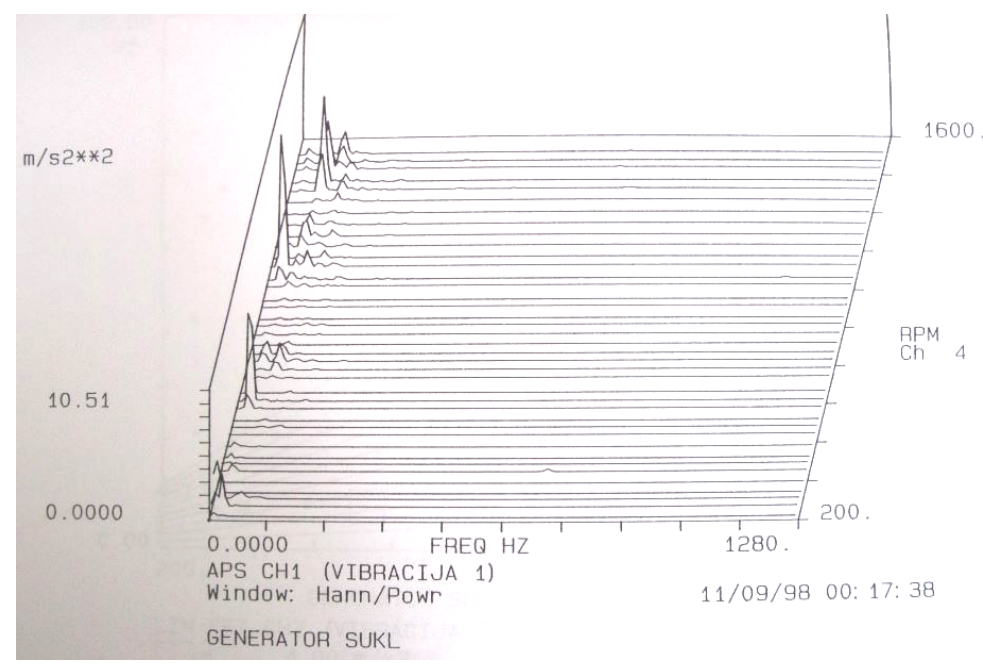

Figure 8 - Spectral map, Syy autospectrum, bearing L5

Puc. 8 - Спектральная карта, Sуy авто-спектр, подшипник L5 Slika 8 - Spektralna mapa, autospektar Syy, ležaj L5 


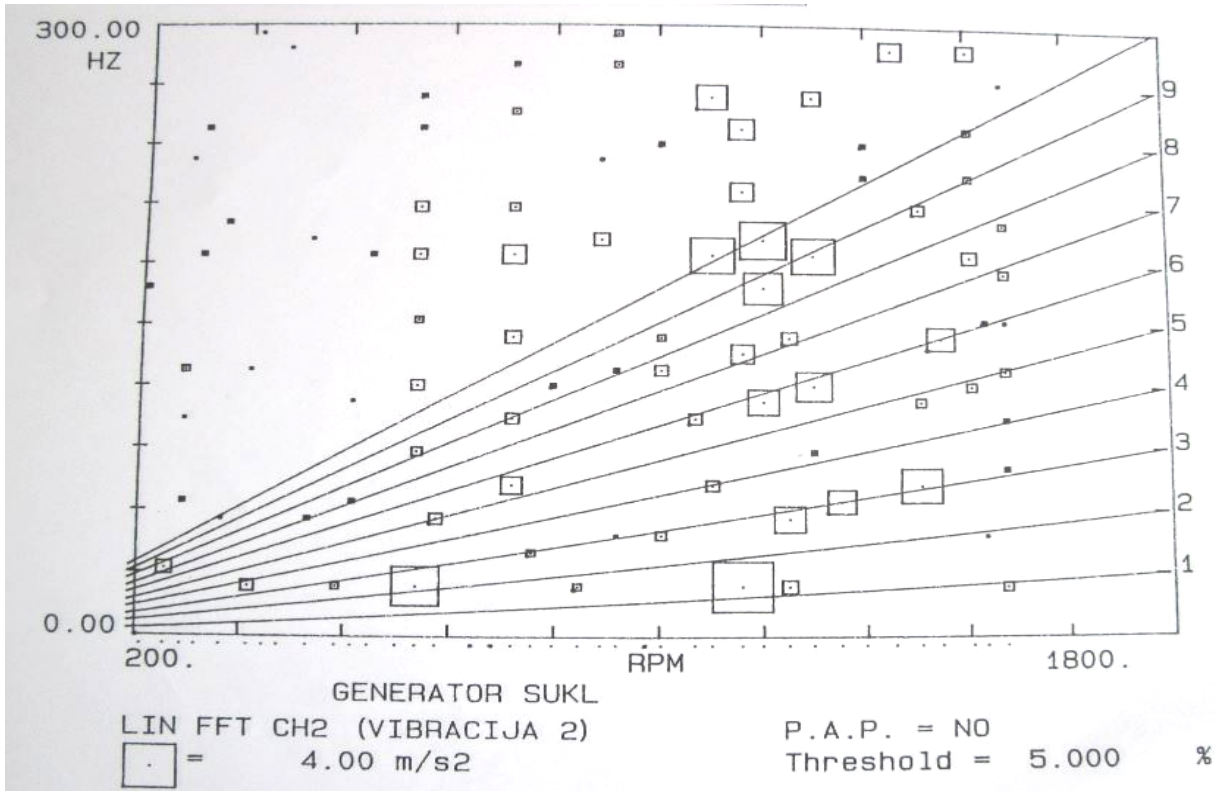

Figure 9 - Campbell diagram, FFT, Syy, bearing L2

Puc. 9 - Диаграмма Кэмпбелла, FFT, Syy, подшипник L2

Slika 9 - Campbell-ov dijagram, FFT, Syy, ležaj L2

From the diagram it can be observed the following.

1. It can be seen several natural frequencies:

- from $2 \ldots . .3 \mathrm{~Hz}$, elastic suspension of the entire plant,

- ca ..... $180 \mathrm{~Hz}$, elasticity support structure,

- ca ...... $500 \mathrm{~Hz}$, elasticity support structure.

2. In the field of high frequency (over $500 \mathrm{~Hz}$ ), you can not see any component that initiated the wear of the bearing.

3 . The spectral map to bed $L 2$, it is clearly of one spectral component of about $500 \mathrm{~Hz}$, at a very low RPM, which is not relevant to the work unit.

\section{Conclusion of the technical state of diesel generating set I}

Based on tests conducted vibration state of the diesel engine, it can be concluded the following: -state aggregates can be characterized as GOOD, Vibration (although male) are characterized by: imbalance that is virtually always present to some extent, secend and fourth harmonic, during the operation of a diesel engine. 
The unit can be used in operational work. Given the long life is necessary to the exploitation of aggregates every 12 months to exert control technical condition of the unit.

\section{Measurement and analysis of vibrations in regime drive electric motor-generating set II}

After a certain time (every 12 months, so we specify measurement intervals) was performed vibrodiagnostics and electromotor II, and to determine the technical soundness and the need for repair of aggregates.

The second unit: electric drive

Table 3 - Measurement results for case 2: aggregate II, electromotor power

Таблица 3 - Результаты измерения второго анализируемого случая: II электростанция с приводом от электродвигателя Tabela 3 - Rezultati merenja za drugi analizirani slučaj:

Il agregat, pogon elektromotorom

\begin{tabular}{|c|c|c|c|c|c|c|c|c|c|c|}
\hline \multicolumn{8}{|c|}{ VIBRACIONO STANJE AGREGATA } & \multicolumn{3}{|c|}{ Tabela II } \\
\hline \multicolumn{3}{|c|}{$\begin{array}{l}\text { Datum ispitivanja: } \\
8.02,1999 \text { god. }\end{array}$} & \multicolumn{6}{|c|}{$\begin{array}{c}\text { Postrojenje: } \\
\text { El.Agregat No-Brake, II, SURČıN }\end{array}$} & \multicolumn{2}{|c|}{$\begin{array}{l}\text { Pogon: } \\
\text { elektromotorom } \\
\text { Br. obrtaja: } 1500 \\
\text { o/min }\end{array}$} \\
\hline \multirow{2}{*}{$\begin{array}{l}\text { LEZAJ } \\
\mathrm{Br} \text {. }\end{array}$} & \multirow{2}{*}{\multicolumn{2}{|c|}{$\begin{array}{l}\text { Ukupna AMS } \\
\text { vrednost } \\
\text { brzine[mm/s] }\end{array}$}} & \multirow{2}{*}{$\begin{array}{l}\text { CREST } \\
\text { faktor }\end{array}$} & \multicolumn{6}{|c|}{ HARMONICI $[\mathrm{mm} / \mathrm{s}]$} & \multirow{2}{*}{$\begin{array}{l}\text { STANJE } \\
\text { PO } \\
\text { ISO } 2372\end{array}$} \\
\hline & & & & 1 & II & III & IV & $\mathrm{V}$ & $\mathrm{V}$ & \\
\hline \multirow{3}{*}{ L 1} & $\mathrm{X}$ & 3.597 & 3.58 & 0.891 & 1.309 & 0.615 & 0.316 & 0.324 & 0.142 & \multirow{3}{*}{$\begin{array}{l}\text { TOLERA- } \\
\text { NTNO }\end{array}$} \\
\hline & $Y$ & 5.371 & 4.13 & 1.557 & 1.997 & 0.640 & 0.761 & 0.356 & 0.06 & \\
\hline & $z$ & 3.366 & 3.37 & 1.339 & 0.741 & 0.800 & 0.175 & 0.069 & 0.242 & \\
\hline \multirow{3}{*}{ L 2} & $x$ & 4.053 & 3.50 & 1.691 & 1.322 & 0.509 & 0.242 & 0.129 & 0.16 & \multirow{3}{*}{$\begin{array}{l}\text { TOLERA- } \\
\text { NTNO }\end{array}$} \\
\hline & Y & 6.97 & 3.90 & 2.695 & 2.115 & 0.431 & 1.010 & 0.600 & 0.119 & \\
\hline & $z$ & 5.214 & 2.03 & 2.594 & 0.941 & 0.448 & 0.560 & 0.473 & 0.198 & \\
\hline \multirow{3}{*}{ L 3} & $\mathrm{x}$ & 11.892 & 4.32 & 6.165 & 4.317 & 0.319 & 0.347 & 0.283 & 0.461 & \multirow{3}{*}{$\begin{array}{l}\text { NEDOZ- } \\
\text { VOLJENO }\end{array}$} \\
\hline & $Y$ & 14.505 & 2.48 & 10.3 & 2.332 & 0.761 & 0.346 & 0.395 & 0.371 & \\
\hline & $z$ & 4.836 & 2.73 & 1.688 & 2.358 & 0.488 & 0.086 & 0.146 & 0.07 & \\
\hline \multirow{3}{*}{ L 4} & $x$ & 6,038 & 2.95 & 2.733 & 1.228 & 0.862 & 0.365 & 0.494 & 0.356 & \multirow{3}{*}{$\begin{array}{l}\text { NEDOZ- } \\
\text { VOLJENO }\end{array}$} \\
\hline & $Y$ & 12,111 & 2.97 & 5.835 & 4.453 & 0.414 & 0.379 & 0.374 & 0.656 & \\
\hline & $z$ & 16.282 & 3.85 & 10.6 & 3.002 & 1.185 & 0.277 & 0.601 & 0.617 & \\
\hline \multirow{3}{*}{ L 5} & $x$ & 9.564 & 4.58 & 5.169 & 1.488 & 1.098 & 0.869 & 0.273 & 0.667 & \multirow{3}{*}{$\begin{array}{l}\text { NEDOZ- } \\
\text { VOLJENO }\end{array}$} \\
\hline & $Y$ & 16.342 & 2.78 & 11.78 & 1.700 & 1.841 & 0.596 & 0.202 & 0.223 & \\
\hline & $z$ & 10.903 & 4.31 & 7.991 & 1.600 & 0.534 & 0.339 & 0.343 & 0.096 & \\
\hline \multirow{3}{*}{ L 6} & $x$ & 7.681 & 2.40 & 4.836 & 1.78 & 0.484 & 0.270 & 0.157 & 0.154 & \multirow{3}{*}{$\begin{array}{l}\text { NEDOZ- } \\
\text { VOLJENO }\end{array}$} \\
\hline & $Y$ & 12.933 & 4.46 & 9.239 & 1.426 & 0.133 & 1.476 & 0.381 & 0.278 & \\
\hline & $z$ & 10.764 & 2.83 & 7.54 & 2.191 & 0.523 & 0.301 & 0.138 & 0.071 & \\
\hline
\end{tabular}




\section{The second unit: Drive diesel engine}

Table 4 - Measurement results for case 2: aggregate II, diesel engine power

Таблица 4 - Результаты измерения второго анализируемого случая: II электростанция с приводом от дизельного двигателя

Tabela 4 - Rezultati merenja za drugii analizirani slučaj: Il agregat, pogon dizel motorom

\begin{tabular}{|c|c|c|c|c|c|c|c|c|c|c|}
\hline \multicolumn{9}{|c|}{ VIBRACIONO STANJE AGREGATA } & \multicolumn{2}{|c|}{ Tabela 1} \\
\hline \multicolumn{3}{|c|}{$\begin{array}{l}\text { Datum ispitivanja: } \\
8.02 .1999 \text { god. }\end{array}$} & \multicolumn{6}{|c|}{$\begin{array}{l}\text { Postrojenje: } \\
\text { El.Agregat No-Brake, II ,SURĆIN }\end{array}$} & \multicolumn{2}{|c|}{$\begin{array}{l}\text { Pogon: } \\
\text { dizel-motorom } \\
\text { Br. obrtaja: } 1500 \\
\text { o/min }\end{array}$} \\
\hline \multirow{2}{*}{$\begin{array}{l}\text { LEŻAJ } \\
\text { Br. }\end{array}$} & \multirow{2}{*}{\multicolumn{2}{|c|}{$\begin{array}{l}\text { Ukupna RMS } \\
\text { vrednost } \\
\text { brzine[mm/s] }\end{array}$}} & \multirow{2}{*}{$\begin{array}{l}\text { CREST } \\
\text { faktor }\end{array}$} & \multicolumn{6}{|c|}{ HARMONICl $[\mathrm{mm} / \mathrm{s}]$} & \multirow{2}{*}{$\begin{array}{l}\text { STANUE } \\
\text { PO } \\
1502372\end{array}$} \\
\hline & & & & 1 & II & III & IV & 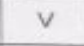 & VI & \\
\hline \multirow{3}{*}{ L 1} & $x$ & 7.91 & 2.31 & 1.308 & 2.675 & 1.546 & 0.503 & 0.9 & 0.974 & \multirow{3}{*}{$\begin{array}{l}\text { TOLERA- } \\
\text { NTNO }\end{array}$} \\
\hline & $Y$ & 6.54 & 4.12 & 3.925 & 1.956 & 0.329 & 0.038 & 0.146 & 0.150 & \\
\hline & $z$ & 3.00 & 3.92 & 1.251 & 0.215 & 0.550 & 0.125 & 0.443 & 0.419 & \\
\hline \multirow{2}{*}{ L 2} & $x$ & 5.61 & 3.18 & 2.413 & 1,163 & 1.491 & 0.278 & 0.184 & 0.084 & \multirow{3}{*}{$\begin{array}{l}\text { TOLERA- } \\
\text { NTNO }\end{array}$} \\
\hline & $\frac{Y}{Z}$ & 9.86 & 3.79 & 6.066 & 1.471 & 0.910 & 0.320 & 0.782 & 0.310 & \\
\hline \multirow{3}{*}{ L 3} & $\frac{2}{x}$ & $\frac{7.65}{9.54}$ & $\frac{4.60}{2.41}$ & $\frac{5.044}{4.997}$ & $\frac{0.594}{3.022}$ & $\frac{1.077}{0.733}$ & $\frac{0.722}{0.195}$ & $\frac{0.138}{0.360}$ & $\frac{0.070}{0.236}$ & \\
\hline & $Y$ & 14.22 & 2.17 & 10.58 & 0.963 & 1.103 & 0.477 & 0.568 & 0.531 & \multirow{2}{*}{$\begin{array}{l}\text { NEDOZ: } \\
\text { VOLJENO }\end{array}$} \\
\hline & $z$ & 7.72 & 3.01 & 5.194 & 1.403 & 0.661 & 0.339 & 0.066 & 0.06 & \\
\hline \multirow{3}{*}{ L 4} & $\bar{x}$ & 9.03 & 2.26 & 4.466 & 2845 & 0.921 & 0.241 & 0.348 & 0.213 & \multirow{3}{*}{$\begin{array}{l}\text { NEDOZ- } \\
\text { VOLJENO }\end{array}$} \\
\hline & $Y$ & 16.12 & 3.54 & 10.22 & 1.099 & 3.784 & 0.227 & 0.608 & 0.185 & \\
\hline & $z$ & 8.30 & 3.63 & 3.708 & 2.304 & 1.546 & 0.355 & 0.293 & 0.093 & \\
\hline \multirow{3}{*}{ L5 } & $x$ & 8.36 & 2.68 & 5.293 & 2.22 & 0.277 & 0.177 & 0.141 & 0.252 & \multirow{3}{*}{$\begin{array}{l}\text { NEDOZ- } \\
\text { VOLJENO }\end{array}$} \\
\hline & $Y$ & 24.85 & 4.17 & 15.38 & 1.587 & 5.748 & 0,908 & 0.45 & 0.776 & \\
\hline & z & 9.04 & 4.33 & 5.845 & 0.783 & 2.403 & 0.002 & 0.001 & 0.003 & \\
\hline \multirow{3}{*}{ L 6} & $x$ & 9.36 & 4.56 & 5.908 & 2.402 & 0.417 & 0.218 & 0.212 & 0.204 & \multirow{3}{*}{$\begin{array}{l}\text { NEDOZ- } \\
\text { VOLJENO }\end{array}$} \\
\hline & $Y$ & 18.41 & 1.72 & 13.58 & 0.799 & 0.314 & 0.922 & 1.925 & 0.87 & \\
\hline & $z$ & 21.74 & 3.38 & 14.18 & 4.94 & 1.371 & 0.558 & 0.163 & 0.532 & \\
\hline \multirow{3}{*}{ MM7 } & $x$ & - & - & - & $=$ & - & - & - & - & \multirow{3}{*}{$\begin{array}{l}\text { NEDOZ- } \\
\text { VOLJENO }\end{array}$} \\
\hline & $Y$ & 11.665 & 3.89 & 3.487 & 2.999 & 4.571 & 0.208 & 0.400 & - & \\
\hline & $z$ & 11.749 & 3.66 & 6.800 & 1.744 & 1.957 & 0.163 & 0.336 & 0.749 & \\
\hline \multirow{3}{*}{ MMB } & $x$ & - & - & - & - & - & - & - & $\cdot$ & \multirow{3}{*}{$\begin{array}{l}\text { NEDOZ: } \\
\text { VOLJENO }\end{array}$} \\
\hline & $Y$ & - & - & - & - & - & - & - & - & \\
\hline & $z$ & 15.702 & 7.82 & 0.784 & 0.206 & 12.61 & 0.353 & 0.282 & 1.467 & \\
\hline \multirow{3}{*}{ MM9 } & $x$ & - & - & - & $=$ & - & - & - & - & \\
\hline & $Y$ & 22.499 & 6.78 & 10.22 & 3.027 & 6.089 & 0.328 & 0.219 & 2.616 & VOLJENO \\
\hline & $z$ & 7.224 & 4.51 & 0.26 & 1.285 & 5.305 & 0.374 & - & - & \\
\hline & $x$ & - & - & - & $=$ & - & - & - & - & $z$ \\
\hline MM10 & $\bar{Y}$ & - &. & - & - & - & - & - & - & VOLJENO \\
\hline & $z$ & 23.327 & 6.93 & 13.24 & 1.913 & 4,739 & 0.409 & 0.410 & 2.616 & \\
\hline
\end{tabular}

On the basis of the examination of the vibrating sheet aggregates, it can be concluded the following:

- general sheet aggregates can be characterized according to the ISO standard as BAD,

- basic Cause of elevated levels of vibration should be sought on the insufficient quality of elastic joints (rubber and metal parts should be replaced immediately) and requires tration of the generating circuits,

- perform replacement friction linings electromagnetic couplings.

- perform replacement of roller bearings: the flywheel aggregates,

- electromotor and generator units. 
Conclusion: The unit is not suitable for further use.

After the overhaul of the generating set is again done the measurement and analysis of vibration parameters. It was found that at the right time repairs done, the values measured vibrations were in accordance with the prescribed norms and standards for vibration. The unit is put into operational work in air traffic control system.

It was found that practically every other year should be made a general overhaul of engines, if it is used in continuous operation. After some time, it has been shown that it is not possible extended exploitation resources of aggregates, although done very well maintain. We had at the end of the case, in one of the aggregates that were changed all roller bearings, couplings, friction linings, but could not reduce the excessive level of vibrations. After many measurements were found to be worn vibroizolatoras (combination of rubber elements and cylindrical springs in a block) under the chassis on which aggregates are aggregates all the circuits 12 pieces.

Worn under the vibroizolators generator aggregates, where we are always measured the highest levels of vibration during use of aggregates.

Accelerated procedure should be accessible procurement of new generating set.

\section{Conclusion}

The paper applied modern vibrodiagnostic methods of measurement and analysis of vibration, in order to determine the technical correctness of diesel generating set, which are of particular importance for the Safety of Air Navigation in the Air Traffic control. Vibrodiagnostic methods for the assessment of the technical safety can be applied in research on all types of generating set: No-Break, Break-short (short interruptions in the power supply), automatic diesel electric generators, mini-hydro power plants in your system are part of the turbine, a variety of flexible couplings, roller bearings, flywheel and generator. The system is similar to a fed-No Break aggregate.

In this way it is done in a planned and preventive maintenance of the generating set, to exclude possibility of occurrence of system failure.

Generating set type No break-in time when they were introduced in the operational work, have proven to be very reliable systems. The main lack was their, high consumption of electricity. Continuously rotating electromotor which in turn drives a generator to which they are all consumers, and in the case a regular supply of electricity from the city network. 
In the event of an interruption in the power supply from the city network, system No-Break aggregate drives a diesel engine. If a longer period of interruption in the normal power supply from the mains, diesel engines consume a significant amount of fuel. What happened was that interruptions last for 2 days. For such cases must be provided large quantities of fuel. For these two No-Break aggregate in reserve is always bilo10.000 liters of diesel fuel in the underground tanks.

In recent years, No-Break generators are replaced with new types of diesel engines, although they still have many locations to use.

The new diesel generators automatically aggregates having a break in the power supply and up to 20 seconds, but after that time included in the system work. To do this would not have happened with diesel engines in the system set UPS systems (uninterruptible power supply), so there is no interruption in the electricity supply.

However, it turned out that these systems have certain disadvantages. If used in conditions on the hills, the mountains where the large atmospheric discharges, very quickly deplete the UPS system modules, which are later very difficult to obtain, since the manufacturers of these devices are changing very quickly and produce new types of UPS systems. It is a very expensive component.

His lack did not have a No-Break sets.

\section{References}

Ličen, H. 2003. Vibrodiagnostics as an element of quality assurance and the reliability of. . In: Scientific conference with international participation, quality, Zenica B \& H,

Standard ISO 2370 Mechanical vibration of machines with operating speeds from 10 to $200 \mathrm{rev} / \mathrm{s}$ in 1974.

Standard ISO 10816 Mechanical vibration of machines in 1974.

Žegarac, N. 2000. Report on the measurement and analysis of vibration on electric generators No-break type, power $175 \mathrm{KVA}$, the cell power system of Regional flight control, Airport Beograd.

Žegarac, N., Ličen, H., \& Zuber, N. 1999. Report on the measurement and analysis of vibration on electric generators set type No-break, with $100 \mathrm{KVA}$, the radar station, Koviona-Beograd.

ИССЛЕДОВАНИЕ ПРИЧИН ПОВЫШЕНОГО УРОВНЯ ВИБРАЦИЙ НА ДИЗЕЛЬНЫХ ЭЛЕКТРОСТАНЦИЯХ В АВИАДИСПЕТЧЕРСКОЙ СЛУЖБЕ - АЭРОПОРТ БЕЛГРАД

Никола П. Жегарац

Сербская академия изобретателей и ученых, Белград, Республика Сербия

ОБЛАСТЬ: машиностроение, электротехника ВИД СТАТЬИ: оригинальная научная статья ЯЗЫК СТАТЬИ: анлийский 
Резюме:

В работе представлены исследования причин повышенного уровня вибраций на дизельных электростанциях в Авиадиспетчерской службе - Аэропорт Белград. Исследованы дизельные электростанции типа No-Break (бесперебойная подача электропитания), мощностью 175 кВА.

Дизельные электростанции используются в качестве резервного источника питания (duplex sistem), в случае перебоя электроснабжения от городских сетей, систем и установок Авиадиспетчерской службы в Аэропорту Белград.

При этом, одна из дизельных электростанций работает в беспрерывном режиме, а вторая представляет собой резервную систему электроснабжения.

Утверждены методы оценки вибрации, технического состояния дизельной электростанции, которые являются неотъемлемой частью документации о содержании и ремонте No-Break дизельных электростанций.

Ключевые слова: дизельные электростанции, измерение и анализ вибраций, уровень вибраций, вибродиагностика, параметры вибрационной характеристики, техническое состояние дизельных электростанций.

ISTRAŽIVANJE UZROKA POVIŠENIH NIVOA VIBRACIJA NA DIZEL-ELEKTROAGREGATIMA U KONTROLI LETENJA - AERODROM BEOGRAD

Nikola P. Žegarac

Srpska akademija izumitelja i naučnika, Beograd, Republika Srbija

OBLAST: mašinstvo, elektrotehnika

VRSTA ČLANKA: originalni naučni članak

JEZIK ČLANKA: engleski

Rezime

U radu su prikazana istraživanja uzroka povišenih nivoa vibracija na dizel-elektroagregatima u Kontroli letenja-Aerodrom Beograd. Dizelelektroagregati su tipa No-Break (nema prekida u napajnaju električnom energijom), snage 175 KVA. Dizel agregati služe kao rezervni izvor napajanja (duplex sistem), u slučaju prekida u redovnom napajanju električnom energijom iz gradske mreže, sistema i uređaja Kontrole letenja na Aerodromu Beograd. Jedan dizel agragat je u neprekidnom radu, dok drugi dizel agregat služi kao rezervni sistem napajanja. Utvrđene su vibrodijagnostičke metode ocene tehničke ispravnosti dizel 
agregata i one su sastavni deo dokumentacije za održavanje i remont No-Break dizel-elektroagregata.

Ključne reči: dizel-elektroagregati, merenje $i$ analiza vibracija, nivoi vibracija, vibrodijagnostika, vibracioni parametri, tehnička ispravnost dizel agregata.

Paper received on / Дата получения работы / Datum prijema članka: 09. 11. 2015.

Manuscript corrections submitted on / Дата получения исправленной версии работы / Datum dostavljanja ispravki rukopisa: 29. 11. 2015.

Paper accepted for publishing on / Дата окончательного согласования работы / Datum konačnog prihvatanja članka za objavljivanje: 01. 12. 2015.

(C) 2015 The Author. Published by Vojnotehnički glasnik / Military Technical Courier (www.vtg.mod.gov.rs, втг.мо.упр.срб). This article is an open access article distributed under the terms and conditions of the Creative Commons Attribution license (http://creativecommons.org/licenses/by/3.0/rs/).

( 2015 Автор. Опубликовано в "Военно-технический вестник / Vojnotehnički glasnik / Military Technical Courier" (www.vtg.mod.gov.rs, втг.мо.упр.срб). Данная статья в открытом доступе и распространяется в соответствии с лицензией "Creative Commons" (http://creativecommons.org/licenses/by/3.0/rs/).

(C) 2015 Autor. Objavio Vojnotehnički glasnik / Military Technical Courier (www.vtg.mod.gov.rs, втг.мо.упр.срб). Ovo je članak otvorenog pristupa i distribuira se u skladu sa Creative Commons licencom (http://creativecommons.org/licenses/by/3.0/rs/). 